\title{
КЕНОТАФ ЗОЛОТООРДЫНСКОГО ВРЕМЕНИ НА МОГИЛЬНИКЕ КОТЫРТАС (Центральный Казахстан)
}

\section{(C) 2019 г. А.И. Кукушкин, Е.А. Дмитриев, И.А. Кукушкин}

Малочисленность изученных памятников XII-XV вв. на территории Центрального Казахстана актуализирует введение в научный оборот любых новых материалов. В рамках данной статьи авторами освещаются результаты исследований золотоордынского кургана на могильнике Котыртас (Шетский р-н, Карагандинская обл.), содержавшего под земляной насыпью оградку из сырцовых кирпичей с пристройкой в виде «портала-пештака». Обращают на себя внимание выявленные следы двух кострищ, столбовые ямки, входная камера с выложенным кладкой порогом, облицовка фасадной стороны постройки, а также обмазка внутриоградного пространства тонким слоем глины. Погребальная камера была заложена в верхней части сырцовыми кирпичами и напоминает сагана, кладка которой опиралась на деревянное перекрытие. Захоронение выявлено не было, что позволяет определить объект как кенотаф. Высказаны некоторые критические замечания в адрес известной хронологии сырцовых оградок, опирающейся на наличие или отсутствие ряда конструктивных элементов. В выводах авторы приходят к необходимости предварительно датировать исследованное сооружение могильника Котыртас в рамках XIII-XIV вв.

Ключевые слова: археология, Центральный Казахстан, Средневековье, золотоордынское время, сырцовая оградка, сагана, кенотаф, исламизация

\section{Введение}

Погребальный обряд населения Центрального Казахстана XII-XV вв. в археологическом плане изучен довольно слабо. Первые работы на памятниках данного времени были проведены М.П. Грязновым у пос. Долинка в 1932-1933 гг., которыми был исследован курган, содержавший сырцовую оградку с двумя безынвентарными захоронениями [Рыков, 1935, с. 64-67]. В 1949 г. А.Х. Маргуланом изучено четыре погребальных комплекса вблизи аула Жартас, где в одном из захоронений выявлен костяк человека, снабженный предметами вооружения и конской упряжи, а так- же двумя монетами [Маргулан, 1959]. Позднее, в 1961 г., в урочище Тасмола было обнаружено новое воинское погребение с двумя серебряными монетами [Кадырбаев, Бурнашева, 1970]. В середине 1980-х гг. база источников пополнилась материалами раскопок еще в двух пунктах. Отрядом Жезказганского областного историкокраеведческого музея исследованы три сооружения на могильнике Домбаул [Усманова, 1986], а С.Г. Боталовым проведены аварийные раскопки кургана аскизского облика на некрополе Кула-Айгыр [Боталов, 1992].

В последнее десятилетие наметилась положительная тенденция в на- 
коплении источников, несмотря на то, что раскопки, в основном, не ведутся систематически. Оперативно были введены в научный оборот новые материалы, полученные при изучении могильников Бозок [Акишев и др., 2008; Хабдулина, 2016], Нураталды-2 [Ломан и др., 2017], Аюлы [Варфоломеев и др., 2017] и Карасуыр [Усманова и др., 2018]. Имеются сведения о проведенных исследованиях в Жанааркинском и Улытауском районах, к сожалению, пока не опубликованные (напр.: [Артефакты Золотой Орды] прим. ред.).

В рамках данной статьи авторами освещаются результаты изучения кургана золотоордынского времени на могильнике Котыртас, проведенного в 2018 г. экспедицией Сарыаркинского археологического института при Карагандинском университете им. академика Е.А. Букетова.

Памятник находится в Шетском районе Карагандинской области, в 93 км юго-восточнее г. Караганды, в 9,5 км юго-восточнее горы Буйректы, в 4,8 км северо-западнее пос. Жанажурт и расположен на относительно ровной площадке правобережья p. Талды, в 0,2 км восточнее линии электропередачи. Северная граница некрополя условно ограничена полевой дорогой.

В ходе обследования погребального поля, которое обильно поросло кустарниками, визуально зафиксированы 12 сооружений в виде курганов, оград без насыпей и выкладок, относящихся к двум историческим периодам: эпохе бронзы (№ 1, 4-12) и средневековью (№ 2-3).

Следует подчеркнуть, что проведенные на памятнике работы были направлены на решение первостепен- ной задачи по исследованию погребальных комплексов бронзового века (объекты № 1, 4-5), а сооружения № 2-3 раскопаны дополнительно, несмотря на их явно средневековый характер (рис. 1).

\section{Описание полученного мате-} риала

Сооружение № 2 до раскопок представляло собой земляной курган овальной формы, размерами $12 \times 11$ м, вытянутый длинной осью по линии С3-ЮВ. С западной стороны зафиксирована западина округлой формы диаметром около 5,5 м, глубиной до $0,4 \mathrm{M}$.

На объекте был разбит раскоп диаметром 12 м, с оставлением двух контрольных бровок, вытянутых по осям С-Ю и 3-В. После снятия дернового слоя вся поверхность раскопа была зачищена с целью выявления кладки подкурганной ограды, после чего земля выбиралась по контуру постройки до уровня материка.

В процессе вскрышных работ на разных уровнях зафиксированы разрозненные кости МРС и лошади, являвшиеся, видимо, остатками тризн или иных, близких по содержанию обрядов поминального характера.

В северо-западном секторе, на глубине 0,59 м, обнаружена металлическая вставка. Она представляла собой прямоугольную в плане рамку, размерами $4 \times 1,5$ см, один из краев которой был скруглен. На тыльной стороне расположены три округлые в сечении шпенька диаметром до 0,2 см, длиной до 0,3 см (рис. 2, 1).

Во внутриоградном пространстве (на глубине 0,55 м) и за его пределами, у юго-западной стенки (на глубине 0,52 м) обнаружено несколько фрагментов железных гвоздей. Они 
Кукушкин А.И., Дмитриев Е.А., Кукушкин И.А. Кенотаф золотоордынского времени на могильнике Котыртас

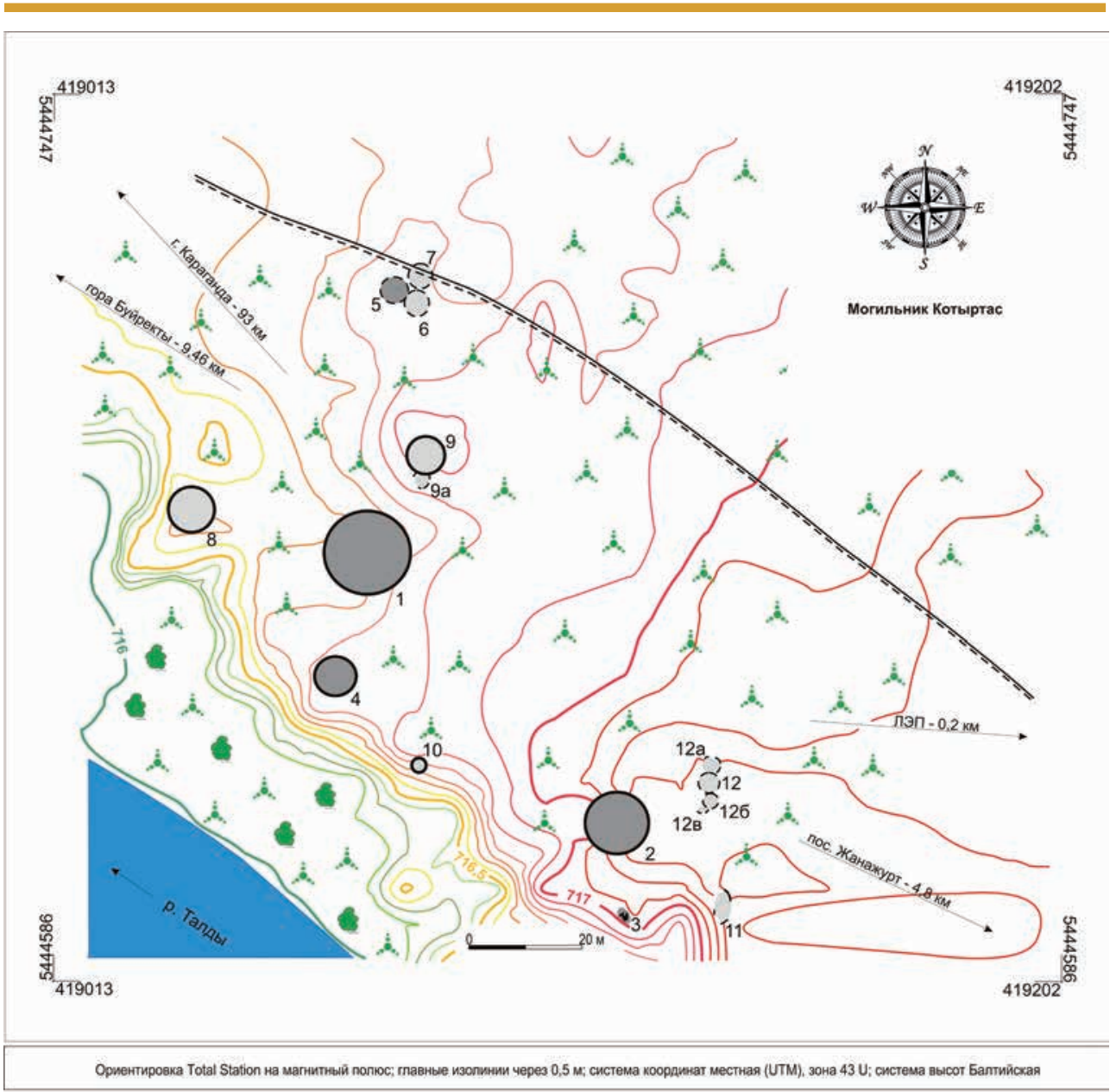

Условные обозначения:

- грунтовая дорога

[2]-кустарник -река [0]-ограда

- изометрические линии

—-дерево [O]-курган [O- -исследованный объект

Рис. 1. Тахеометрический план могильника Котыртас. Исполнитель: Е.А. Дмитриев

Fig. 1. The total station plan of the Kotyrtas burial ground. Realized Dmitriev E.A

имели подквадратную и шестиугольную в плане форму шляпки, размерами $1,5 \times 1,5$ см и $2 \times 1,5$ см соответственно. С тыльной стороны перпендикулярно шляпкам располагались стержни, подквадратные в сечении, размерами $0,3 \times 0,3$ и $0,4 \times 0,4$ см соответственно. Заостренные концы были частично обломлены. Максимальная длина сохранившейся части изделий составила 4,2 см (рис. 2, 2-5).
После снятия насыпи на подкурганной площадке расчищена подпрямоугольная в плане формы ограда размерами 5,3×4,9-4,75 м, высотой до 0,5 м, сложенная кладкой в 1,5 ряда шириной (около 0,6 м) из двух отличных по размерности комплектов сырцовых кирпичей. С юго-восточной стороны, к ограде примыкает дополнительная пристройка в виде «пештака», длиной до 1,2 м. 


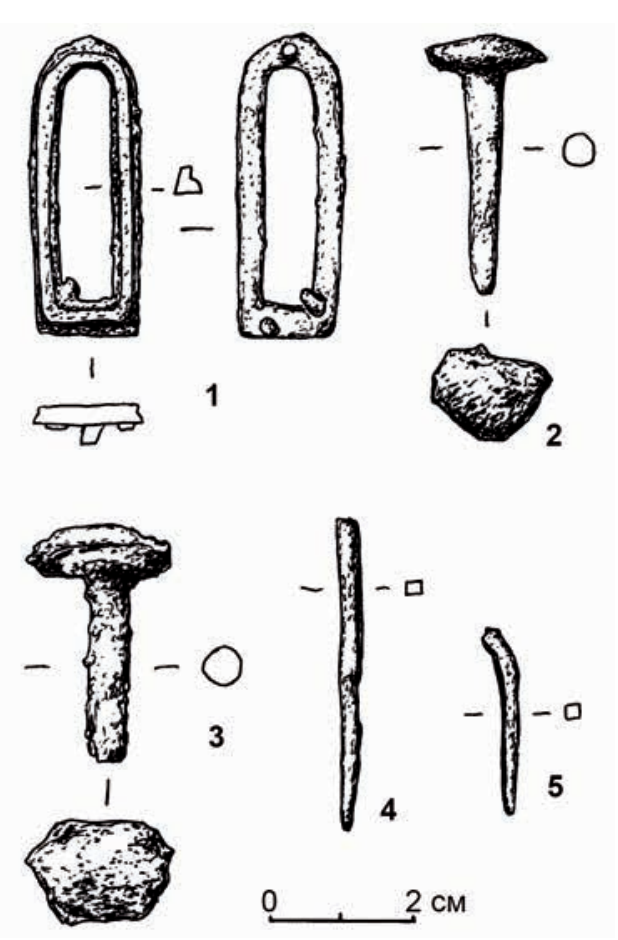

Рис. 2. Могильник Котыртас. Находки. 1 - металлическая вставка; 2-5-железные гвозди

Fig. 2. The burial ground of Kotyrtas. Finds: 1 -metal insert; 2-5-iron nails

Фасадная часть сооружения имела облицовку, зафиксированную на расстоянии 0,4 м от стенок, сохранившуюся на высоту до 0,10,15 м в виде прослойки грунта черного цвета.

В юго-восточной стене мазара был устроен проход шириной 0,8 м, пол которого вымощен кирпичами, образуя порог.

У входа, ближе к южной стенке «пештака», зафиксировано овальное пятно кострища диаметром 0,5 м, мощностью до 0,03 м. Напротив входа, на расстоянии 0,5 м, выявлены две столбовые ямки, расположенные друг за другом. Первая - округлой формы, диаметром 0,2 м, глубиной до 0,1 м; вторая - овальная в плане формы, размерами $0,3 \times 0,2 \mathrm{M}$, глубиной около $0,1 \mathrm{M}$.

Пол внутриоградного пространства был залит тонким, но плотным и твердым слоем светло-желтой глины, на котором в центральной части выявлены остатки кострища округлой формы, диаметром 1,5 м, мощностью 0,2 м (рис. 3).

После снятия заливки у северозападной стенки ограды зафиксировано погребение, которое представляло собой грунтовую яму, овальной в плане формы, размерами 2,3×0,85×1,0 м, ориентированную длинной осью по линии С3-ЮВ. В процессе выборки заполнения могилы было установлено, что ее верхняя часть была заложена кладкой из сырцовых кирпичей (сагана), мощностью в пять рядов, в нижней части которой обнаружены перерубленные кости лошади (череп и передние конечности) и ветви деревьев. Причем кости черепа находились в центральной части, на глубине 0,35 м от верхних краев могилы, между вторым и третьим рядами кладки. На глубине 0,7-0,8 м зафиксированы фрагменты дерева, вероятно, оставшиеся от сгнившего перекрытия (рис. 4). Захоронение не обнаружено.

Сооружение № 3 до раскопок фиксировалось по двум крупным, выступающим на современной поверхности камням. На объекте был разбит раскоп диаметром 2 м. После снятия поверхностного слоя расчищена выкладка из пяти камней, три из которых (наиболее крупные) вытянуты по линии СВ-Ю3. Находок не обнаружено.

\section{Обсуждение}

На данный момент сырцовые оградки в Центральном Казахстане раскопаны на могильниках у пос. Долинка [Рыков, 1935, рис. 55], Бозок 
Кукушкин А.И., Дмитриев Е.А., Кукушкин И.А. Кенотаф золотоордынского времени на могильнике Котыртас
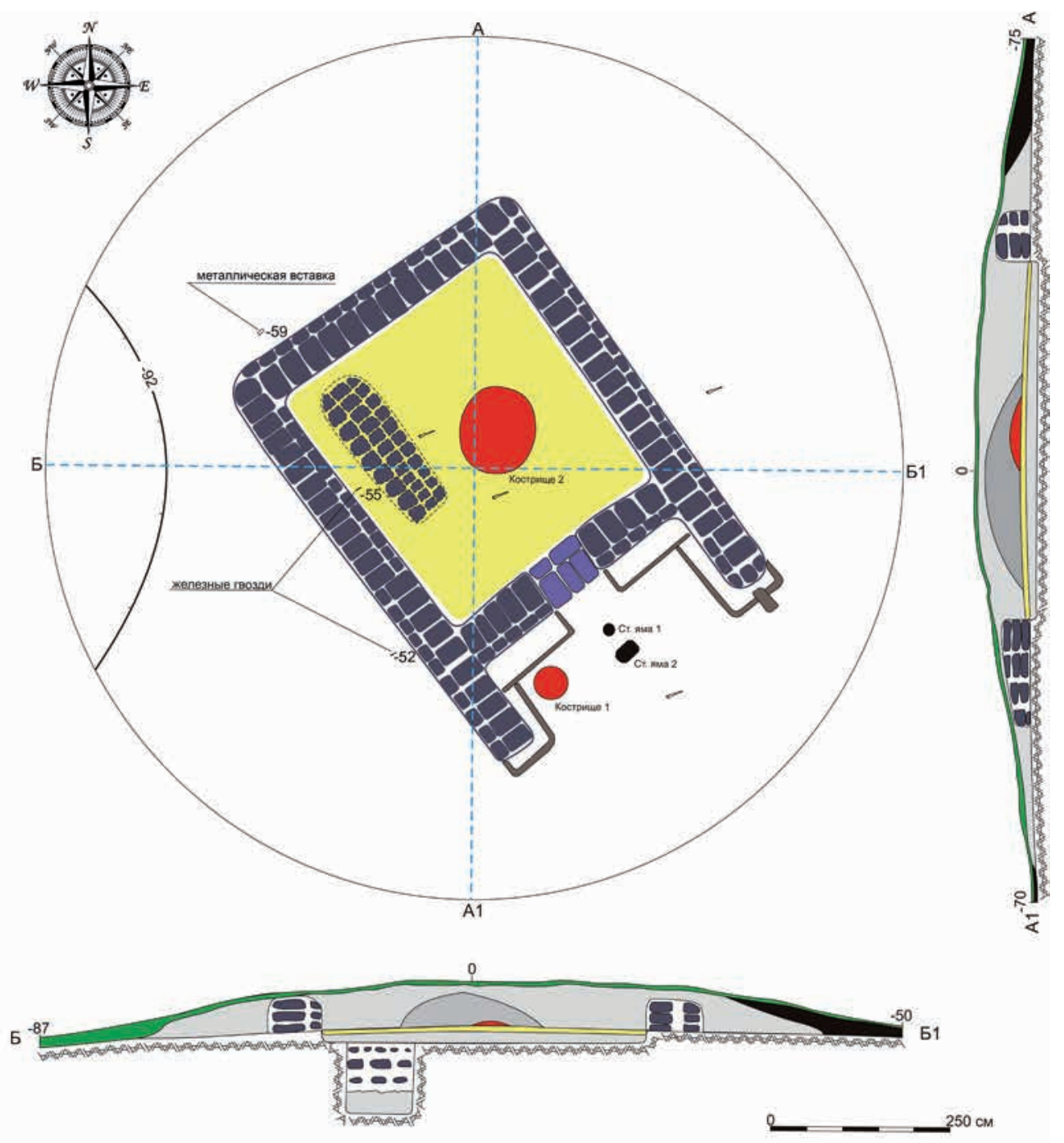

Условные обозначения:

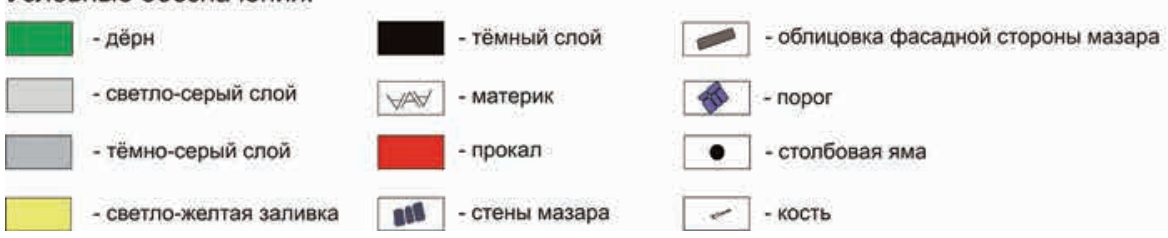

Рис. 3. Могильник Котыртас. План и профили сооружения № 2

Fig. 3. The burial ground of Kotyrtas. Plan and profiles of the construction no. 2

[Хабдулина, 2016] и Нураталды-2 [Ломан и др., 2017], расположенных в Карагандинской и Акмолинской областях. Считаем необходимым оговорить, что исследованный М.П. Гряз- новым объект, скорее всего, датируется XIV-XVI вв., т.е. лишь нижняя хронологическая граница попадает в интересующий нас период. На более молодой возраст сооружения указыва- 


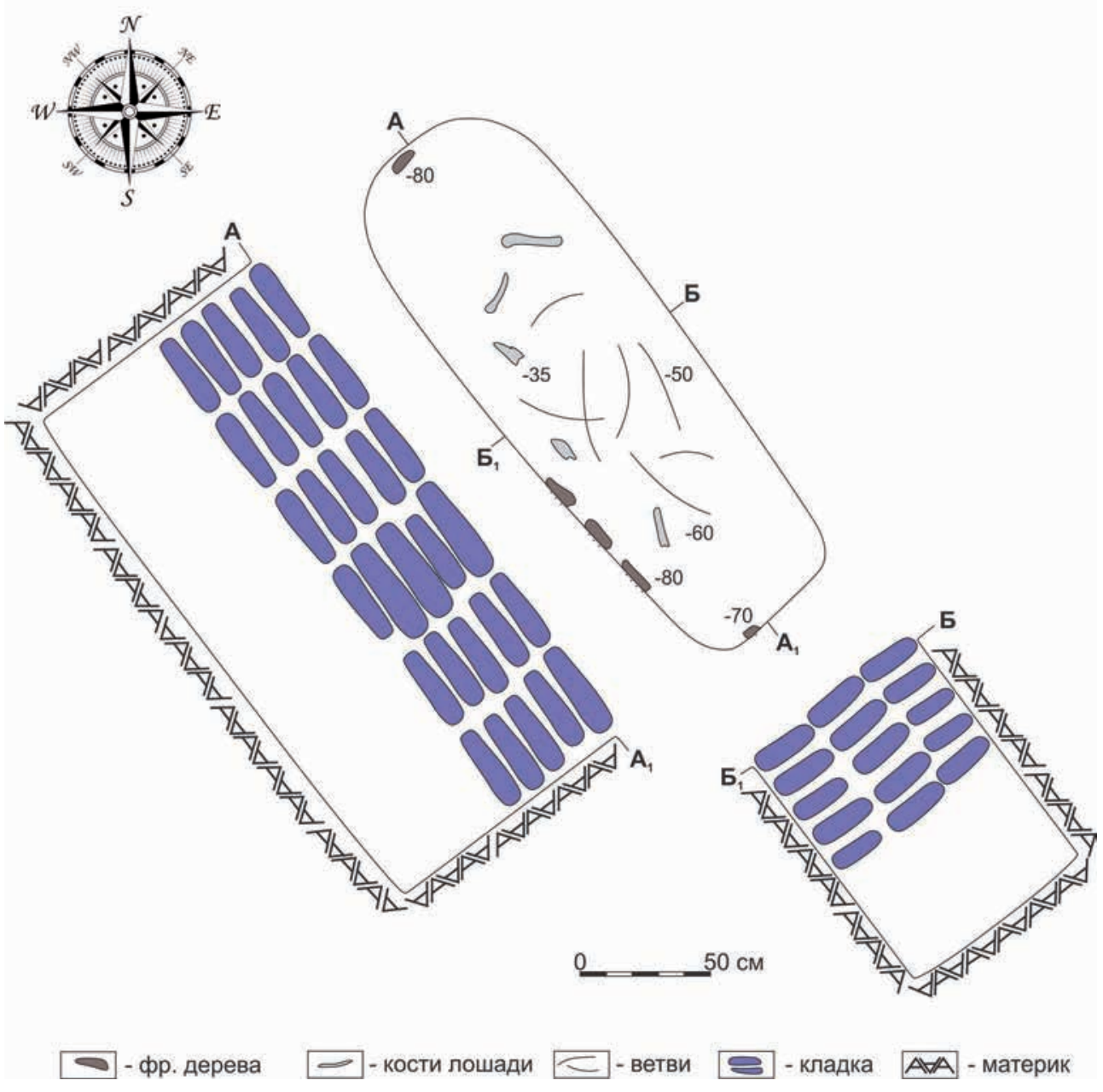

Рис. 4. Могильник Котыртас. План и разрезы погребальной камеры

Fig. 4. Kotirtas burial ground. Plan and sections of the burial chamber

ют следующие признаки, свойственные мусульманской погребальной обрядности: наличие сагана над обоими захоронениями в ограде, их безынвентарность, характерное положение тел и направление лицевого отдела черепа на юго-запад [Рыков, 1935, с. 65] в сторону Каабы.

В типологическом плане обозначенные постройки неоднородны и могут быть предварительно разделены на две группы: простые сооружения четырехугольной формы (Долин- ка, Бозок и Нураталды-2 - сооружение № 1) и четырехугольные ограды с «порталами-пештаками», пристроенными с юго-восточной стороны (Котыртас, Нураталды-2 - сооружение № 2). Думается, в виду малочисленности исследованных объектов, дальнейшее сравнение их архитектурных особенностей будет излишним.

Примеры возведения стенок сырцовой ограды кладкой в 1,5 ряда шириной известны, в частности, на могильниках Мокринский-I [Марык- 
Кукушкин А.И., Дмитриев Е.А., Кукушкин И.А. Кенотаф золотоордынского времени на могильнике Котыртас

син, 2012, рис. 1-3, рис. 2-3], Караултобе [Кригер, Марыксин, 2008, рис. 2] и Нураталды-2 (рис. 5). Найденные в процессе снятия насыпи кости МРС и лошади во множестве встречены на других погребальных комплексах золотоордынского времени [Кригер, Марыксин, 2008, с. 193-194; Марыксин, 2012, с. 112; Васильев, 2006, с. 213] и являются, видимо, свидетельствами проведения поминальных обрядов.

В этом ракурс, вполне резонно предположение Е.П. Мыськова и Д.В. Васильева о том, что некоторое время оградки с совершенными захоронениями могли быть рассчитаны на посещение родственниками [Васильев, 2006, с. 212], во всяком случае, на это также указывает ряд находок на могильниках Нураталды-2 (обломки глиняной посуды) и Котыртас (весь металлический инвентарь и кости животных). Дополнительными аргументами следует признать фиксацию двух кострищ в Котыртасе и устройство характерного для сырцовых оградок входа. Правда, остается немного неясным назначение двух столбов перед входом, не исключено, что они являлись коновязными.

Закладка части могильной ямы сырцовыми кирпичами - известная практика, называемая сагана. Как правило, в нижней части, над погребенным, устанавливалось деревянное перекрытие, поддерживающее верхнюю сырцовую конструкцию [Кригер, Марыксин, 2008, с. 193-195]. Однако, в связи с отсутствием останков умершего, считаем возможным, тривиально определить исследованное сооружение могильника Котыртас в качестве кенотафа.

Причем, необходимо подчеркнуть, что найденные рубленые кости лошади располагались непосредственно над перекрытием, в частности между нижними рядами сырцовых блоков (вероятно, сагана слегка просела в могильную яму, чем и объясняется данное обстоятельство их нахождения) и не связаны с ритуальной заменой тела человека. Считаем возможным сослаться на два известных случая. Так, на могильнике Караултобе в погребении 1 сооружения 2 были обнаружены в засыпи кости коровы [Кригер, Марыксин, 2008, с. 194] при наличии полноценного не потревоженного захоронения, над которым была устроена сагана [Кригер, Марыксин, 2008, рис. 5], а в погребении № 4 мавзолея № 5 некрополя Бозок рубленые кости лошади или КРС находились в самой могиле, рядом с человеческими останками [Хабдулина, 2016, с. 261].

Обнаруженный в ходе исследования кургана Котыртас инвентарь представлен фрагментированными железными гвоздями, металлической вставкой и не является датирующим.

Железные гвозди широко известны в золотоордынских погребальных комплексах и концентрируются преимущественно в могилах [Марыксин, 2012, с. 112].

Металлическая вставка, видимо, крепилась к окончанию ремня с помощью шпеньков и аналогична близким по форме, но цельным концевым бляхам отдела А (по Г.А. ФедоровуДавыдову), суммарные признаки которого могут быть охарактеризованы удлиненной формой, округлым передним окончанием и ровным задним краем [Федоров-Давыдов, 1966, c. 60-61].

Трактовка причин появления сырцовых оградок под курганными насыпями неоднозначна. Д.В. Васи- 


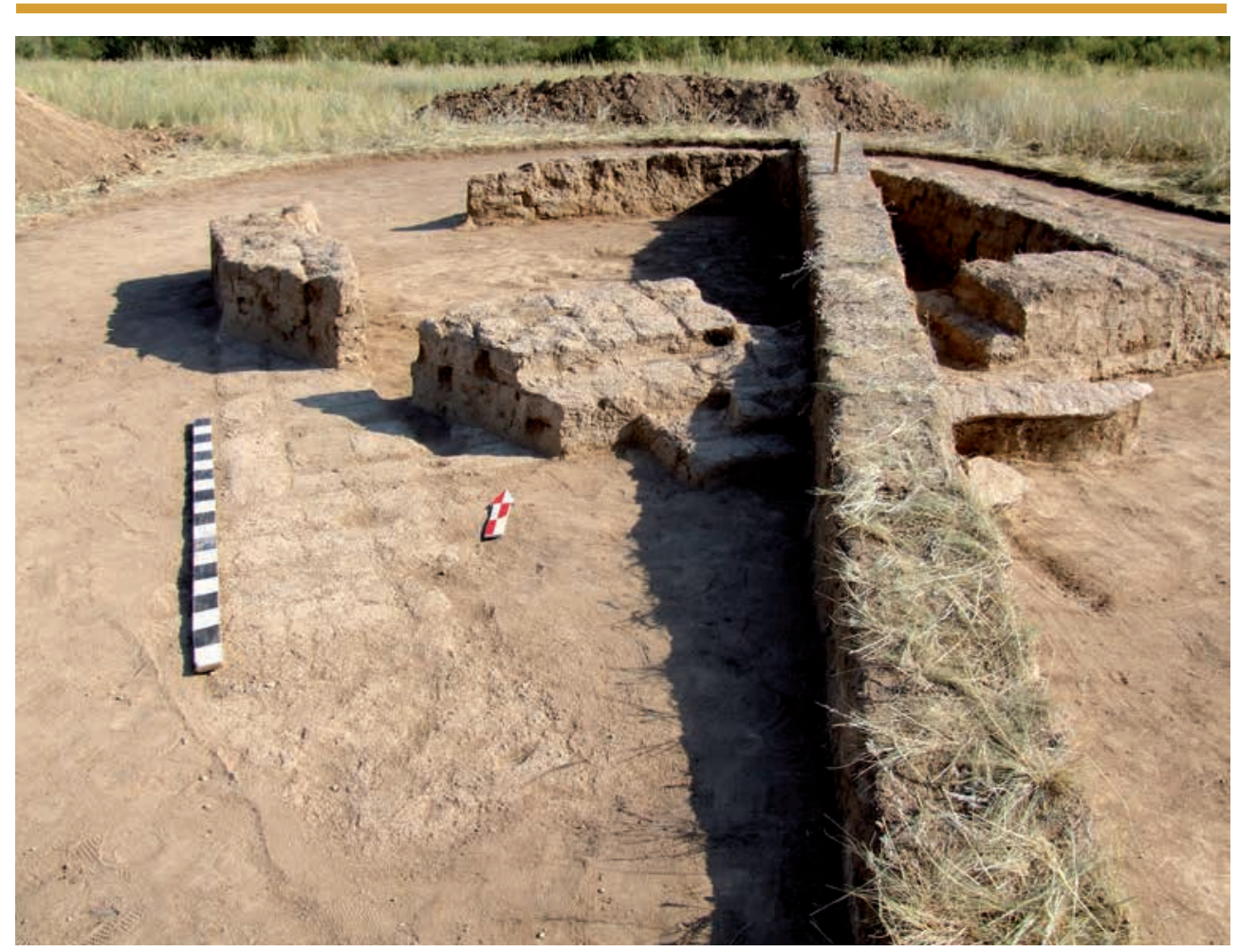

Рис. 5. Могильник Нураталды-2. Сооружение № 2. Вид с юго-запада. Фото А.И. Кукушкина

Fig. 5. The burial ground of Nurataldy-2. Building no. 2. View from the south-west. Photo by Kukushkin A.I.

льевым приведен историографический обзор существующих мнений, которые составляют два лагеря исследователей: сторонников исламского влияния и приверженцев идеи о дальнейшем развитии языческой традиции [Васильев, 2006, с. 208-210].

Действительно, подкурганные оградки (возведенные из другого строительного материала) известны в предшествующее время на территории Центрального Казахстана и открыты, к примеру, на древнетюркских памятниках Кетабан и Ащекен Сораны, исследованных авторами в 2018 г. и освещенных пока предварительным сообщением [Кукушкин и др., 2019]. Однако, как справедливо подмечено Д.В. Васильевым: «хотя и не ясно - связано ли появление оградок с мусульманизацией населения степи напрямую, можно уверенно сказать, что этот элемент погребального обряда испытал влияние ислама в XIV веке - об этом говорят пристройки с юга “пештаки”, появляющиеся у поздних оградок» (цит. по: [Васильев, 2006, c. 210-211]), копирующие в комплексе с оградой планиграфическое строение двухкамерного или портальнокупольного мавзолея [Ракушин, 1993, c. 173], что нами наблюдалось при исследовании могильников Нураталды-2 (рис. 5) и Котыртас (рис. 6).

При этом хотелось бы высказать критические замечания в адрес предложенной А.И. Ракушиным, на основании типологического анализа, 
Кукушкин А.И., Дмитриев Е.А., Кукушкин И.А. Кенотаф золотоордынского времени на могильнике Котыртас

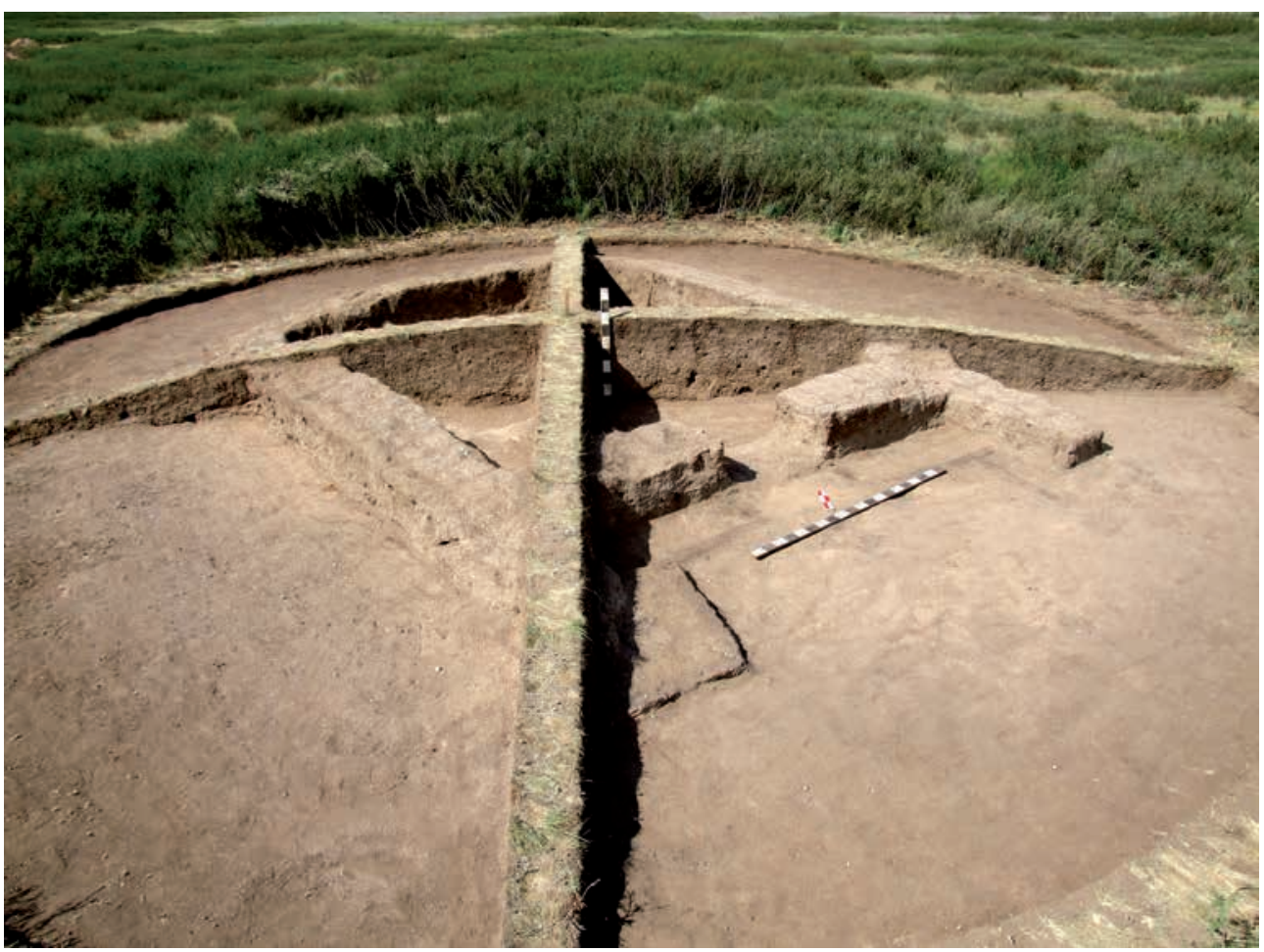

Рис. 6. Могильник Котьртас. Сооружение № 2. Вид с юга. Фото Е.А. Дмитриева

Fig. 6. The burial ground of Kotyrtas. Building no 2. View from the south. Photo by Dmitriev E.A.

хронологии сырцовых оградок. Согласно исследователю, отдельные конструктивные особенности данных сооружений служат хронологическими индикаторами. В нашем случае особо интересно, что оградки с заполнением внутреннего пространства, в том числе, глиняной обмазкой, причислены к наиболее ранним. Во втором периоде распространяются простые квадратные сооружения без внутренней вымостки или обмазки. Наиболее поздние постройки получают дополнительную пристройку с юга, наподобие «портала-пештака» [Ракушин, 1993, с. 171-173].

Однако подчеркнем, что сооружение 2 могильника Нураталды-2 [Ломан и др., с. 213] и ограда Котыртас представляют собой согласно вы- шеописанной типологии одновременно сооружения первого и третьего периодов (наличие внутренней глиняной обмазки и «портала-пештака»). В этом ракурсе считаем возможным поддержать критику Е.П. Мыськова в адрес схемы А.И. Ракушина [Мыськов, 2003, с. 225].

\section{Заключение}

Таким образом, исследованное сооружение на могильнике Котыртас отражает процесс постепенной исламизации населения Центрального Казахстана, которое в данном случае отмечается благодаря устройству дополнительной пристройки к сырцовой ограде с юго-восточной стороны, что копирует в целом планиграфическое строение двухкамерного или портально-купольного мазара. К при- 
знакам мусульманской погребальной традиции следует отнести возведение над могилой конструкции типа сагана. Время строительства данного сооружения может быть предваритель- но определено в рамках XIII-XIV вв., в соответствии с датировкой территориально ближайших построек аналогичного типа.

\section{ЛИТЕРАТУРА}

1 Акишев К.А., Хасенова Б.М., Мотов Ю.А. К вопросу о монгольских погребениях XIII-XIV вв. (по материалам некрополя Бозок) // Бозок в панораме средневековых культур Евразии: матер. Междунар. полевого семинара, посвящ. 80-летию со дня рождения видного казахского ученого-археолога К.А. Акишева (г. Астана, 29-30 июля 2004 г.). Астана: ЕНУ им. Л.Н. Гумилева, 2008. С. 56-65.

2 Артефакты Золотой Орды. Официальный сайт газеты «Казахстанская правда». URL: https://kazpravda.kz/articles/view/artefakti-zolotoi-ordi (дата обращения: 30.10.2019 г.)

3 Боталов С.Г. Аскизский курган монгольского времени Кула-Айгыр // РА. 1992. № 2. C. 230-239.

4 Варфоломеев В.В., Кукушкин И.А., Дмитриев Е.А. Средневековое погребение у аула Аюлы // История и археология Семиречья: сб. науч. ст. и публикаций памяти Ю.А. Мотова. Алматы: Институт археологии им. А.Х. Маргулана, 2017. Вып. 5. С. 167-173.

5 Васильев Д.В. Статистический анализ золотоордынских захоронений в подкурганных оградках // Вопросы истории и археологии Западного Казахстана. 2006. № 1-2. C. 208-220.

6 Кадырбаев М.К., Бурнашева Р.3. Погребение кыпчака первой половины XIV в. из могильника Тасмола // По следам древних культур Казахстана. Алма-Ата: изд-во «Наука» КазССР, 1970. С. 42-53.

7 Кригер В.А., Марыксин Д.В. Могильник Караултобе (к вопросу о захоронениях в сырцовых оградках) // Вопросы истории и археологии Западного Казахстана. 2008. № 1. С. 193-206.

8 Кукушкин И.А., Дмитриев Е.А., Кукушкин А.И. Предварительные результаты исследований памятников тюркского времени Центрального Казахстана в 2018 году // Кочевые империи Евразии в свете археологических и междисциплинарных исследований сб. науч. ст. IV Междунар. конгресса средневековой археологии евразийских степей, посвящ. 100-летию российской академической археологии (г. Улан-Удэ, 16-21 сентября 2019 г.). В: 2 кн. / Отв. ред. Б.В. Базаров, Н.Н. Крадин. Улан-Удэ: БНЦ CO РAH, 2019. Кн. 1. C. 135-137.

9 Ломан В.Г., Дмитриев Е.А., Кукушкин И.А., Кукушкин А.И. Золотоордынские погребения могильника Нураталды-2 // Археологическое наследие Центрального Казахстана: изучение и сохранение: сб. науч. ст., посвящ. 70-летию организации Центрально-Казахстанской археологической экспедиции Академии наук Казахстана. Алматы: НИЦИА «Бегазы-Тасмола», 2017. С. 209-218.

10 Маргулан A.X. Раскопки погребения воина XIV века в долине реки Нуры // ТИИАЭ АН КазССР. 1959. Т. 7. С. 248-261.

11 Марыксин Д.В. Комплекс сырцовых оградок у аула Айдархан // Вопросы истории и археологии Западного Казахстана. 2012. № 1. С. 111-119.

12 Мыськов Е.П. Погребальные сооружения с кирпичными оградами могильника Маляевка VI у северо-западного пригорода Царёвского Городища // Нижневолжский археологический вестник. 2003. Вып. 6. С. 216-235. 
Кукушкин А.И., Дмитриев Е.А., Кукушкин И.А. Кенотаф золотоордынского времени на могильнике Котыртас

13 Ракушин А.И. Подкурганные кирпичные сооружения золотоордынского времени в Нижнем Поволжье (предварительные выводы) // Археологические вести. Саратов: Изд-во Саратовского гос. ун-та, 1993. Вып. 1. С. 170-175.

14 Рыков П.С. Работы в совхозе «Гигант» (Караганда). Отчет о работах // Археологические работы Академии на новостройках в 1932-1933 гг. М.-Л.: ОГИЗ Государственное социально-экономическое издательство, 1935. Вып. 109-110. Т. II. C. 40-68.

15 Усманова Э.Р. Новые материалы по эпохе кочевников из Джезказганской области // Ранний железный век и средневековье Урало-Иртышского междуречья. Челябинск: Изд-е Башкирского ун-та, 1987. С. 99-105.

16 Усманова Э.Р., Дремов И.И., Панюшкина И.П., Колбина А.В. Монгольские воины Улуса Джучи по материалам могильника Карасуыр (Улытау, Центральный Казахстан) // АЭАЕ. 2018. Т. 46, № 2. С. 106-113.

17 Федоров-Давыдов Г.А. Кочевники Восточной Европы под властью золотоордынских ханов. Археологические памятники. М.: Изд-во Московского университета, 1966. $276 \mathrm{c.}$

18 Хабдулина М.К. Мусульманский некрополь городища Бозок (Центральный Казахстан) // Материалы Конгресса исламской археологии России и стран СНГ (г. Казань, 26-28 сентября 2016 г.). Казань: Институт археологии имени А.Х. Халикова АН PT, 2016. C. 250-261.

\section{Сведения об авторах:}

Кукушкин Алексей Игоревич - докторант $\mathrm{PhD}$, научный сотрудник, Сарыаркинский археологический институт, Карагандинский университет имени Е.А. Букетова (г. Караганды, Казахстан); tatarlandia@mail.ru

Дмитриев Евгений Анатольевич - аспирант, Алтайский государственный университет (г. Барнаул, РФ), младший научный сотрудник, Сарыаркинский археологический институт, Карагандинский университет имени Е.А. Букетова (г. Караганды, Казахстан); yevgenii1992@mail.ru

Кукушкин Игорь Алексеевич - кандидат исторических наук, ведущий научный сотрудник, Сарыаркинский археологический институт, Карагандинский университет имени Е.А. Букетова (г. Караганды, Казахстан); sai@ksu.kz

\section{ҚОТЫРТАС ҚОРЫМЫНДАҒЫ АЛТЫН ОРДА ДӘУІРІНДЕГІ КЕНОТАФ (Орталық Қазақстан)}

\section{А.И. Кукушкин, Е.А. Дмитриев, И.А. Кукушкин}

Орталық Қазақстан аумағында зерттелген XII-XV ғғ. ескерткіштер санының аздығы ғылыми айналымға кез келген жаңа материалдарды енгізудің өзектілігін артыра түседі. Осы мақала аясында авторлармен «портал-пештак» түріндегі жапсарлас салынған сырлы кірпіштен жасалған қоршауды қамтитын Қотыртас (Қарағанды обл., Шет ауданы) қорымындағы Алтын Орда қорғанының зерттеу нәтижелері баяндалады. Екі алаудың анықталған іздері, бағана шұңқырлары, табалдырығы төселген кіру камерасы, құрылыстың қасбеттік жағын қаптау және қалашық ішіндегі кеңістікті балшықтың жұқа қабатымен жағу назар аударады. Жерлеу камерасы сырлы кірпіштермен салынған және ағаш жабынына салынған сағанды еске салады. Бұл кенотаф сияқты нысанды анықтауға мүмкіндік береді. Бірқатар конструктивтік элементтердің болуына немесе болмауына сүйенетін сырлы қоршауларының белгілі хронологиясына қатысты кейбір сыни ескертулер айтылды. Сараптаманың қорытындысында бағдарлама авторлары, зерттелген 
Қотыртас обасының құрылысы XIII-XIV ғғ. аясында деген қажеттілікке келіп, алдын ала уақытын қояды.

Түйін сөздер: археология, Орталық Қазақстан, Орта ғасыр, Алтынорда уақыты, сырлы қоршау, сағана, кенотаф, исламдандыру

\section{CENOTAPH OF THE GOLDEN HORDE TIME \\ AT THE TOMBSTONE OF KOTYRTAS \\ (Central Kazakhstan)}

\section{A.I. Kukushkin, E.A. Dmitriev, I.A. Kukushkin}

The small number of the XII-XV centuries monuments studied on the territory of Central Kazakhstan, the introduction of any new materials into the scientific circulation is being updated. In the framework of this article, the authors highlight the results of the studies of the Golden Horde mound at the Kotyrtas burial ground (Shet district of the Karagandy region), which contained an adobe brick fence with an annex in the form of a "peshtak portal" under the earthen mound. Noteworthy are the traces of two fireplaces, pillar pits, the entrance chamber with a masonry threshold, the facade side of the building and the coating of the inner-city space with a thin layer of clay. The burial chamber was laid in the upper part with raw bricks and resembles a sagan (brick tombstone of Muslim graves), the masonry of which rested on a wooden floor. No burial was detected, which allows determining the object as a cenotaph. Some criticisms have been made to the well-known chronology of raw fences, based on the presence or absence of a number of structural elements. In the conclusions, the authors come to the need to date the investigated structure of the Kotyrtas burial ground in the XIII-XIV centuries.

Keywords: archaeology, Central Kazakhstan, the Middle Ages, the Golden Horde time, raw fence, sagan, cenotaph, Islamization

\section{REFERENCES}

1 Akishev, K. A., Khasenova, B. M., Motov, Yu. A. 2008. In Bozok v panorame srednevekovyh kultur Evrazii (Bozok in the panorama of medieval cultures of Eurasia). Astana: L.N. Gumilev Eurasian National University, 56-65 (in Russian).

2 In: URL: https://kazpravda.kz/articles/view/artefakti-zolotoi-ordi

3 Botalov S.G. 1992. In Rossiyskaya arheologiya (Russian archeology), 2, 230-239 (in Russian).

4 Varfolomeev, V. V., Kukushkin, I. A., Dmitriev, E. A. 2017. In Istoriya i arheologiya Semirechiya (History and archeology of Semirechye), 5. Almaty: A.Kh. Margulan Institute of Archaeology, 167-173 (in Russian).

5 Vasiliev, D. V. 2006. In Voprosy istorii i arheologii Zapadnogo Kazahstana (Questions of history and archeology of Western Kazakhstan), 1-2, 208-220 (in Russian).

6 Kadyrbyaev, M. K., Burnasheva, R. Z. 1970. In Po sledam drevnih kultur Kazahstana (Following the tracks of ancient cultures of Kazakhstan). Alma-Ata: "Nauka" Publ., 42-53 (in Russian).

7 Kriger, V. A., Maryksin, D. V. 2008. In Voprosy istorii i arheologii Zapadnogo Kazahstana (Questions of history and archeology of Western Kazakhstan), 1, 193-206 (in Russian).

8 Kukushkin, I. A., Dmitriev, E. A., Kukushkin, A. I. 2019. In Bazarov, B. V., Kradin, N. N. (Eds.) Kochevye imperii Evrazii v svete arheologicheskih i mezhdisciplinarnyh issledovanij (The nomadic empires of Eurasia in the light of archaeological and interdisciplinary research), 1. Ulan-Ude: BNC SO RAN, 135-137 (in Russian). 
9 Loman, V. G., Dmitriev, E. A., Kukushkin, I. A., Kukushkin, A. I. 2017. In Beisenov, A. Z., Loman, V. G. (Eds.) Arheologicheskoe nasledie Centralnogo Kazahstana: izuchenie i sohranenie (Archaeological Heritage of Central Kazakhstan: Study and Preservation). Almaty: "Begazy-Tasmola" Publ., 209-218 (in Russian).

10 Margulan, A. Kh. 1959. In Trudy Instituta istorii, arheologii i etnografii Akademii nauk Kazahskoj SSR (Proceedings of the Institute of History, Archeology and Ethnography of the Academy of Sciences of the Kazakh SSR), 7, 248-261 (in Russian).

11 Maryksin, D. V. 2012. In Voprosy istorii $i$ arheologii Zapadnogo Kazahstana (Questions of history and archeology of Western Kazakhstan), 1, 111-119 (in Russian).

12 Myskov, E. P. 2003. In Nizhnevolzhskij arheologicheskij vestnik (Lower Volga Archaeological Bulletin), 6, 216-235 (in Russian).

13 Rakushin, A. I. 1993. In Arheologicheskie vesti (Archaeological News), 1. Saratov: Saratov State University Publ., 170-175 (in Russian).

14 Rykov, P. S. 1935. In Arheologicheskie raboty Akademii na novostrojkah v 19321933 gg. (The archaeological work of the Academy in new buildings in 1932-1933.), 109-110, II. Moscow-Leningrad: OGIZ State Socio-Economic Publishing House, 40-68 (in Russian).

15 Usmanova, E. R. 1987. In Rannij zheleznyj vek i srednevekovie Uralo-Irtyshskogo mezhdurechiya (Early Iron Age and Middle Ages of the Ural-Irtysh interfluve.). Chelyabinsk: "Bashkir University" Publ., 99-105 (in Russian).

16 Usmanova, E. R., Dremov, I. I., Panyushkina, I. P., Kolbina, A. V. 2018. In Arheologiya, etnografiya i antropologiya Evrazii (Archeology, Ethnography and Anthropology of Eurasia.), 46, 2, 106-113 (in Russian).

17 Fedorov-Davydov, G. A. 1966. Kochevniki Vostochnoj Evropy pod vlastiyu zolotoordynskih hanov. Arheologicheskie pamyatniki (Nomads of Eastern Europe under the rule of the Golden Horde khans. Archaeological sites). Moscow: "Moskow University" Publ. (in Russian).

18 Khabdulina, M. K. 2016. Materialy Kongressa islamskoj arheologii Rossii i stran SNG (Materials of the Congress of Islamic Archeology of Russia and the CIS). Kazan: Institute of Archaeology named after A.Kh. Khalikov, 250-261 (in Russian).

\section{About the Authors:}

Kukushkin Alexey I. PhD doctoral student, researcher, Saryarka Archaeological Institute, academician Ye.A. Buketov Karagandy University, Karagandy, Kazakhstan; tatarlandia@mail.ru

Dmitriev Evgeniy A. Postgraduate student, Altay State University (Barnaul, RF), junior researcher, Saryarka Archaeological Institute, academician Ye.A. Buketov Karagandy University, Karagandy, Kazakhstan; yevgenii1992@mail.ru

Kukushkin Igor A. Candidate of historical sciences, Leading researcher, Saryarka Archaeological Institute, academician Ye.A. Buketov Karagandy University, Karagandy, Kazakhstan; sai@ksu.kz

Мүдделер қақтығысы туралы ақпаратты ашу. Авторлар мүдделер қақтығысының жоқтығын мәлімдейді. / Раскрытие информации о конфликте интересов. Авторы заявляют об отсутствии конфликта интересов.

/ Disclosure of conflict of interest information. The authors claims no conflict of interest.

Мақала туралы ақпарат / Информация о статье / Information about the article.

Редакцияға түсті / Поступила в редакцию / Entered the editorial office: 30.10.2019.

Рецензенттер мақұлдаған / Одобрено рецензентами / Approved by reviewers: 06.11.2019.

Жариялауға қабылданды / Принята к публикации / Accepted for publication: 13.11.2019. 